\title{
REFLEKSJE NAD PERSPEKTYWAMI ZACHOWANIA STANOWISK NEOLITYCZNYCH W DORZECZU TAZŻYNY
}

SŁowa KLuCzowe: stanowiska neolityczne; dorzecze Tążyny; Kujawy; ochrona stanowisk archeologicznych

Keywords: the Neolithic sites; Tążyna river basin; Kuyavia; preservation archaeological sites

W czerwcu 1912 r. dwaj szacowni obywatele Aleksandrowa Kujawskiego - wówczas zwanego Pogranicznym - dziennikarz i literat Ludwik Stanisław Korotyński oraz weterynarz Konstanty Krynicki podjęli dość nietypową wyprawę. Dodać wypada, że panowie dzielili zainteresowania filologiczne i fizjograficzne, z którymi w parze szła autentyczna pasja badawcza. Nie może więc dziwić, że postanowili oni rozwiązać zagadkę ,prawdziwej” nazwy rzeki wymienionej w tytule niniejszej pracy. W tym celu, umówiwszy bryczkę, po sutym obiedzie, udali się na wycieczkę do Służewa - w odwiedziny u księdza kanonika Wawrzyńca Waszaka. U niego, jako rodowitego Kujawiaka, mieli nadzieję zasięgnąć wiarygodnych informacji. Ekspedycja obu panów - w wersji sportretowanej przez Marię Danilewicz-Zielińską (2000) - przypominała skrzyżowanie przygód bohaterów „Klubu Pickwicka” z ,budziejowicką anabasis” dobrego wojaka Szwejka. W końcu jednak, nieco skonsternowani różnymi wersjami nazwy rzeki, popijając pejsachówkę w miejscowym zajeździe, usłyszeli określenie - w ich mniemaniu jedyne właściwe - czyli właśnie „Tążyna”.

Powyższy anegdotyczny wstęp kryje dość istotną treść. Współczesny językoznawca Jerzy Duma (1999: 87) przytacza 14 wersji zapisu nazwy Tążyny. Wszystkie łączy związek ze staropolskim czasownikiem „tężeć”, czyli gęstnieć, „czynić tęgim, sztywnieć, zagęszczać, koncentrować, np. tężyć sól” 
(Długosz-Kurczabowa 2003: 77). Co szczególnie istotne, z zasolenia wód powierzchniowych dorzecza Tążyny prawdopodobnie korzystano już w młodszej epoce kamienia (Rzepecki 2014: 565), co plasowałoby ten region wśród wyjątkowych miejsc na mapie Europy. Tym większą wagę przypisać należy problemowi przetrwania stanowisk neolitycznych; temu właśnie zagadnieniu poświęcony jest niniejszy szkic.

\section{I}

Przed rozwinięciem głównego wątku rozważań należy jednak pokrótce nakreślić środowiskowe dyspozycje dorzecza Tążyny oraz główne kierunki ich wykorzystania w neolicie.

Dla budowy geologicznej Kujaw charakterystyczna jest m.in. obecność, stosunkowo pytko zalegających, wysadów solnych (Tarka 1992). Co istotne, penetrowane przez wodę indukują one powierzchniowe występowanie źródeł solankowych. Kształt rzeźby doliny Tążyny warunkowała z kolei rozmaitość procesów glacjalnych. Jej bezpośrednie zaplecze tworzą płaskie wysoczyzny morenowe zbudowane z glin, zaś rynnę doliny, wciętą o ok. 15-20 m, zajmują sandry i tzw. sandry dziurawe - będące efektem wytapiania się brył martwego lodu (Domańska i inni 2013). Po ustapieniu lodowca dało to w efekcie skomplikowany układ gleb, w którym najwyższe partie terenu zajmują doskonałe czarne ziemie oraz gleby brunatne, zaś w dolinie dominują utwory bielicoziemne (sandry) oraz hydrogeniczne (sandry dziurawe). Jest oczywiste, że w przeszłości towarzyszyło temu znaczne zróżnicowanie pokrywy roślinnej (od olsów i łęgów po wielogatunkowe lasy liściaste; Matuszkiewicz 2008, 2010). Na bioróżnorodność dorzecza Tążyny składają się również halofity - czyli słonorośla rozpoznane m.in. przez Jadwigę Wilkoń-Michalską (1963, 1971).

W ujęciu regionalnym (tj. kujawskim) cezury neolitu tworzą dwa procesy (Kośko 1981; Czerniak 1994; Szmyt 2013). Pierwszy związany jest z inicjacją osadnictwa społeczności kultury ceramiki wstęgowej rytej (ok. 5500 BC; Czerniak 1994; Grygiel 2004; Pyzel 2010), drugi zaś - finałem dezintegracji kultury pucharów lejkowatych ${ }^{1}$ (ok. 2350 BC; np.: Przybył 2009; Szmyt 2013). Ponad trzy tysiące lat dzielących oba te „wydarzenia” pozostawiło w krajobrazie kulturowym dorzecza Tążyny bardzo liczne relikty osadnictwa. Część $\mathrm{z}$ nich uwikłana jest w podstawowe wątki narracji o epoce - w jej środkowoeuropejskim wymiarze. Nie ma potrzeby, aby dokonywać tu szczegółowych

\footnotetext{
${ }^{1} \mathrm{~W}$ pracy zastosowano następujące skróty: KAK - kultura amfor kulistych; KB-K - kultura brzesko-kujawska; KCSZ - kultura ceramiki sznurowej; KCWR - kultura ceramiki wstęgowej rytej; KPL - kultura pucharów lejkowatych.
} 
prezentacji. Zainteresowanego Czytelnika odsyłam do publikacji źródłowych, zwrócić jednak warto uwagę na kilka obserwacji o znaczeniu fundamentalnym.

Pojawienie się najstarszych rolników KCWR dobrze poświadczają odkrycia ze stanowiska Grabie 4, gm. Aleksandrów Kujawski (Czerniak 1994). Cechą charakterystyczną osady jest jej położenie w obrębie żyznych gleb czarnych, co stanowi doskonałą manifestację oportunizmu ekologicznego i kulturowego jej mieszkańców. Przede wszystkim zainteresowani oni byli reprodukcją wzorców zachowań znanych ze strefy naddunajskiej (por. Rzepecki 2013). Na tym tle wyjątkowego znaczenia nabierają obserwacje z okresu ok. trzysta lat późniejszego. Dotyczą one szeregu stanowisk KCWR zadokumentowanych na piaszczystym dnie doliny Tążyny. Najbardziej znane z nich to stanowisko Podgaj 32, gm. Aleksandrów Kujawski. Reprezentuje ono niewielkie obozowisko o wyraźnie selekcjonowanym charakterze zbioru ceramiki (niemal wyłącznie „kuchennej”) oraz krzemieniach surowcowo i technologicznie bliskich wzorcom mezolitycznym (por. Czerniak 1988, 1994; Domańska 1988, 1995). Interpretacje tego zespołu wpisują się w dyskusje o zasięgu paneuropejskim: akulturacji lub asymilacji ludności mezolitycznej (Kośko 1981; Czerniak 1988, 1994: 120-121) oraz próbach kolonizacji nowych ekumen w związku z ,przeludnieniem” strefy gleb o najwyższej przydatności rolniczej (Czerniak 1988). Kolejne odkrycia, ze stanowisk Chlewiska 132, gm. Dąbrowa Biskupia (Domańska, Rzepecki 2009) oraz Wiktoryn 2, gm. Wieniec (Domańska, Rzepecki 2010) pozwoliły istotnie zmodyfikować wcześniejsze ustalenia. Jednocześnie ujawniły one znacznie bardziej złożony (pod względem funkcjonalnym) charakter opisywanej grupy stanowisk oraz wprost sugerują „taktyczną” próbę kolonizacji strefy bielicoziemnej (Rzepecki 2013). Cytowana praca wyraźnie akcentowała znaczenie norm oceny krajobrazu dla sposobu doboru siedlisk, a dokładniej - uwikłanie, w proces podejmowania decyzji o doborze miejsc zasiedlenia, przesłanek o charakterze pozautylitarnym. Funkcjonowanie norm topolifii i topofobii pozwalało na porządkowanie i waloryzację znanej przestrzeni. Fiasko prób „wczesnowstęgowego” zasiedlenia dna doliny Tążyny stało się w tym przypadku fundamentem wyraźnego ograniczenia aktywności osadników KB-K do obszaru gleb o najwyższych walorach (Rzepecki 2013).

Kolejny rozdział w historii doliny Tążyny otworzyło pojawienie się społeczności KPL. Unikając zbędnego wikłania się w dyskusje genetyczne (por. Rzepecki 2004) trzeba podkreślić, że jej przedstawiciele pojawili się tu zapewne już u zarania funkcjonowania tego systemu kulturowego (ok. 4400 BC; np. niepublikowane wyniki badań ze stanowiska Podgaj 16/16A; Czerniak 1994: 154). Co więcej, kilka stanowisk z analizowanego obszaru ma charakter 
„kanoniczny” dla dyskusji nad KPL. Używając „klucza” chronologicznego, jako pierwsze wspomnienia wymaga stanowisko Podgaj 7A, gm. Aleksandrów Kujawski (Czerniak, Kośko 1993; Czerniak 1994). Jego eksploracja ujawniła m.in. relikty, zaopatrzonego w palisadę drewnianą, grobowca typu Niedźwiedź (Rzepecki 2011) - obecnie najlepiej znanej konstrukcji tego typu z terenu Kujaw. Z kolei dobrze czytelne ślady „wczesnej” (ok. 4200-3800 BC) półziemianki wraz z towarzyszącym jej wyposażeniem odkryto na stanowisku w Poczałkowie 38, gm. Aleksandrów Kujawski (Rzepecki 2004; Domańska 2013). Bardzo bogate pozostałości osadnictwa $\mathrm{z}$ tego okresu zarejestrowano także na stanowisku Przybranówek 43, gm. Aleksandrów Kujawski, z którego znane jest m.in. unikatowe dłuto miedziane (Czerniak, Kośko 1993; Domańska, Rzepecki 2001; Rzepecki 2004; Domańska 2013). Szczególnie w pracach piszącego te słowa omawiany zespół traktowany był jako przykład osady zasiedlanej rotacyjnie przez ludność „pucharową” (Rzepecki 2004: 113). Obecnie, biorąc pod uwagę wyniki badań na stanowisku w Wilkostowie 23/24, gm. Aleksandrów Kujawski, wnioski te należy traktować z większą ostrożnością. Wspominając o samym Wilkostowie 23/24 trzeba wyraźnie zaakcentować wyjątkowy status tego zespołu - stanowi on jedną z najlepiej rozpoznanych osad KPL w Europie. Na powierzchni ok. 1 ha zarejestrowano relikty 11 domów, dziesiątki dobrze zachowanych obiektów gospodarczych oraz ok. 50 tys. fragmentów ceramiki wraz z licznymi źródłami wykonanymi z innych surowców (Rzepecki 2014). Bayesowkie symulacje oznaczeń radiowęglowych wyraźnie wskazują, że osada zasiedlona była stosunkowo krótko, przez okres ok. 40-80 lat, pomiędzy 3547/3508 i 3486/3442 BC. Szereg danych, m.in. wyniki analiz kości zwierzęcych (Waszczuk 2014), odcisków zbóż na ceramice (Abramów 2014) oraz rdzenia geochemicznego (Okupny i inni 2014) wyraźnie poświadczają, że podstawą utrzymania mieszkańców osady była uprawa pszenicy uzupełnione przez hodowlę bydła, świni i kozy. Podkreślenia wymaga znaczny stopień opresyjności ekologicznej stosowanego systemu rolnego (Rzepecki 2014). Jakkolwiek preferowanym celem osadnictwa KPL było środowisko dziewiczych lasów klimaksowych, to masowe zastosowanie ognia do pozyskania terenów dla upraw szybko musiało zmieniać kondycję lokalnych ekosystemów.

Stanowisko Wilkostowo 23/24 dokumentuje również prolog regionalnej ekspansji ludności KAK (Rzepecki 2014). Wkraczała ona wówczas na teren gleb piaszczystych, wykazując daleko idące związki z cechami sieci osadniczej KPL (Szmyt 1996). Nie wykluczając istnienia antagonizmów dzielących obie społeczności (tj. KPL i KAK; Czebreszuk, Szmyt 2010) wydaje się jednak, że w ogólnym rozrachunku był to układ w pełni symbiotyczny (por. Wiślański 
1969: 244-245). W przypadku samej KAK wspomnieć należy trzy stanowiska. Przybranowo 10 i Opoki 7, gm. Aleksandrów Kujawski (Chachlikowski, Czebreszuk 1990; Szmyt 1996: 141) stanowią przykłady wielodomowych osad. Z kolei na stanowisku Goszczewo 13, gm. Aleksandrów Kujawski (Chachlikowski 1990, 1997) rozpoznano unikatową odkrywkową kopalnię eratyków wraz z towarzyszącą jej pracownią obróbki surowca kamiennego.

Kolejny etap zasiedlenia strefy środkowej doliny Tążyny wyznacza pojawienie się społeczności pastoralnych, związanych z KCSZ. Niewielkie obozowiska $\mathrm{z}$ tego okresu znane są m.in. z badań na stanowiskach Podgaj 32, gm. Aleksandrów Kujawski i Zarębowo 21, gm. Zakrzewo (Czebreszuk 1996). Z omawianego terenu pochodzą też obiekty sepulkralne ludności „sznurowej”, można tu wymienić groby z Podgaja 6A (Czebreszuk 1996; Pospieszny 2009) oraz kurhan z dookolnym rowkiem z Przybranówka 43, gm. Aleksandrów Kujawski (Domańska, Rzepecki 2001). Pomijam w tym miejscu charakterystykę społeczności „leśnych”; jakkolwiek ich stanowiska znane są z omawianego obszaru, to nie stały się one dotychczas celem prac wykopaliskowych (por. Jóźwiak 2001).

Powyższe résumé jednoznacznie poświadcza, że waga cytowanych odkryć pozwala plasować zlewnię Tążyny w kontekście obszarów kluczowych dla poznania neolitu środkowoeuropejskiego. Obserwować tu możemy m.in. proces postępującej domestykacji przestrzeni, która w efekcie objęła nie tylko rozbudowę palety technik rolniczych, lecz również technologii związanych z wykorzystaniem innych zasobów środowiska (solowarstwo, kamieniarstwo).

\section{II}

Choć omawiany teren już pod koniec lat pięćdziesiątych XX wieku stał się celem akcji penetracyjnych (Wiślański 1969), to dopiero planowa działalność Zespołu Badań Kujaw Instytutu Prahistorii Uniwersytetu im. Adama Mickiewicza spowodowała lawinowy przyrost źródeł (por. Jaskanis 1992, 1993). Świadectwem tego jest chociażby dokumentacja sporządzona $\mathrm{w}$ ramach realizacji programu Archeologicznego Zdjęcia Polski. Trzeba wyraźnie podkreślić wyjątkowo profesjonalne wykonanie kart AZP dla stanowisk z doliny Tażyny; autorem znacznej ich części był Józef Bednarczyk. Nie jest to uwaga jedynie grzecznościowa, rzetelność informacji archiwalnych pozwala bowiem na porównanie stanu zachowania stanowisk neolitycznych na przestrzeni ostatnich trzydziestu - czterdziestu lat. Całościowy opis zagrożeń dla zasobów archeologicznych 
na omawianym terenie stanie się tematem osobnej publikacji. Warto jednak już teraz naszkicować kilka uwag, które wynikają z obserwacji prowadzonych przez piszącego te słowa.

Zarysowany wyżej stan zróżnicowania ekologicznego dorzecza Tążyny jest współcześnie podstawą realizacji bardzo zróżnicowanych strategii gospodarczych. Związane są one zarówno z gospodarką rolną, jak i wydobyciem kopalin (Program Ochrony Środowiska...; Studium uwarunkowań i kierunków zagospodarowania przestrzennego...).

Warto zauważyć, że dla kierunków rolniczego wykorzystania gleb w ostatnim ćwierćwieczu ogromne znaczenie miały przekształcenia struktury własnościowej. Przełom roku 1989 przyniósł m.in. zanik państwowych i spółdzielczych gospodarstw rolnych. Z kolei od roku 2002 obserwowany jest proces stopniowego zmniejszania się gospodarstw o najmniejszej powierzchni, co stanowi świadectwo postępującej profesjonalizacji i specjalizacji produkcji rolnej. W przypadku gleb o najlepszych warunkach glebowych przyniosło to poważne zwiększenie udziału upraw warzyw i owoców (np. truskawek). Z kolei grunty o gorszych parametrach użytkowych wykorzystywane są obecnie głównie dla produkcji ziemniaków i żyta. Pozornie nie ma to wiele wspólnego ze stanem zachowania źródeł archeologicznych; stosowane zabiegi agrotechniczne (przede wszystkim orka) nie skutkują istotnym, przekraczającym pewną „średnią”, zwiększeniem ingerencji w substancję zabytkową stanowisk. Jednak tak pożądanemu, z gospodarczego punktu widzenia, wzrostowi powierzchni upraw warzyw towarzyszy radykalne zwiększenie potrzeb ich długotrwałego przechowywania. Powszechnie stosuje się tu najtańsze i najprostsze rozwiązanie, czyli kopcowanie. Szczególnie nadają się do tego grunty o luźnej strukturze - zabezpieczają one bowiem przed nadmiernym gromadzeniem wilgoci. W przypadku stanowisk zlokalizowanych na bezpośrednim zapleczu budynków gospodarczych najczęściej oznacza to ich narażenie na całkowite zniszczenie. Unikając zbędnego mnożenia przykładów chciałbym zwrócić tu uwagę na wieś Przybranówek. We wczesnych latach osiemdziesiątych XX wieku na jej gruntach rozpoznano ogółem 34 stanowiska datowane na neolit. Jak wyżej zaznaczałem, kilka z nich stało się celem prac wykopaliskowych (właściwie: sondażowych) i dostarczyły źródeł dokumentujących szczególnie istotne procesy domestykacji krajobrazu doliny Tażyny. Niestety, ulokowanie kopców pod warzywa niemal całkowicie zniszczyło dwa najważniejsze stanowiska (Przybranówek 4 i Przybranówek 43, gm. Aleksandrów Kujawski). Można obecnie szacować, że aż około 15\% neolitycznych z terenu wsi zostało w ten sposób bezpowrotnie zdewastowanych. 
Zmniejszenie opłacalności produkcji rolnej na obszarach gleb najsłabszych (wykształconych na podłożu piasku) wywołuje oczywistą reakcję w sposobach ich gospodarczego wykorzystania. Wskazać tu można dwie podstawowe strategie: zalesiania tych obszarów lub ich wykorzystania jako źródła kopalin (piasek, żwir). Ta ostatnia ma nieco starszą metrykę - sięgającą przełomu lat siedemdziesiątych i osiemdziesiątych XX wieku - i od niej rozpocznę dalszą analizę.

W dorzeczu Tążyny ulokowanych jest dziesięć złóż surowców pospolitych (piasek i żwir; Studium uwarunkowań i kierunków zagospodarowania przestrzennego...). W przypadku dwóch złóż ulokowanych na gruntach wsi Opoki ich wykorzystanie zostało wstrzymane (odkrywki: Tążyna II i Opoki). Trzy dalsze kopalnie są obecnie eksploatowane (Tążyna I, Opoki II, Podgaj), a rozpoczęcie wydobycia planowane jest w obrębie złóż: Opoki I, Zgoda, Tążyna III, Konradowo I oraz Wilkostowo I. Prócz tego w obrębie dorzecza Tążyny doraźnie funkcjonują nielegalne (rozgrzebiskowe) piaskownie i żwirownie. Nie trzeba chyba dłużej przekonywać, że eksploatacja kopalin jest czynnikiem ostatecznie niszczącym (wręcz: anihilującym) źródła archeologiczne. Dobrym przykładem są tu losy stanowisk zlokalizowanych na gruntach wsi Opoki i Podgaj. W latach osiemdziesiattych XX wieku na terenie pierwszej z wymienionych wsi potwierdzono istnienie 34 , zaś drugiej - 51 stanowisk neolitycznych. Już wówczas część z nich była systematycznie dewastowana, a akcje ratownicze ograniczały się do zabezpieczenia ścian wyrobisk (Opoki 7, Podgaj 6A, Podgaj 7A, gm. Aleksandrów Kujawski; Andrałojć, Woźniak 1988; Czerniak, Kośko 1993; Chachlikowski 1994). Obecnie żaden z cytowanych kompleksów już nie istnieje. Co gorsza, omawiany problem dotyka także stanowisk znanych jedynie z badań powierzchniowych. Sytuacja szczególnie dramatyczna dotyczy Opok. Bardzo zwarty zespół stanowisk neolitycznych (głównie KPL) został w tym przypadku zniszczony w ok. 30\%. Nieco lepiej sytuacja wygląda $\mathrm{w}$ przypadku Podgaja, gdzie dotychczas zdewastowano ok. $13 \%$ stanowisk.

Biorąc pod uwagę plany powiększenia obszarów wydobywczych proces dalszego niszczenia stanowisk wydaje się być przesądzony (Studium uwarunkowań i kierunków zagospodarowania przestrzennego...). W najbliższych latach skokowo wzrosną m.in. zagrożenia dla reliktów osadnictwa neolitycznego znanego z Wilkostowa.

Rządowe plany zwiększenia stopnia zalesienia Polski znajdują dotychczas stosunkowo niewielkie przełożenie na sytuację w dorzeczu Tążyny. Dane z terenu gminy Aleksandrów Kujawski wskazują, że w latach 2002-2010 powierzchnia lasów zwiększyła się o ok. 43 ha (Studium uwarunkowań i kierunków zagospo- 
darowania przestrzennego...). Jednocześnie jednak cytowany dokument przewiduje kontynuację zalesień na gruntach o najsłabszej przydatności rolniczej. $\mathrm{Z}$ perspektywy naszej nauki oznacza to, że stanowiska położone w takich kontekstach glebowych narażone będą na zabiegi przygotowujące zalesienie, przede wszystkim - głęboko penetrującą profil gleby orkę leśną (Jaworski 2011).

\section{III}

Jak wyżej dowodziłem, w dorzeczu Tążyny zadokumentowano bardzo bogate relikty osadnictwa neolitycznego, a skala problemów łączących się z nimi ma wyjątkowe (paneuropejskie) znaczenie poznawcze. Większość stanowisk rozpoznana została jednak wyłącznie napowierzchniowo, a jedynie nieliczne badane były przy użyciu metod wykopaliskowych, tylko Wilkostowo 23/24 eksplorowano na szeroką skalę.

$\mathrm{Z}$ wybitnym statusem interpretacyjnym omawianego mikroregionu niekorzystnie korespondują perspektywy dalszego zachowania stanowisk archeologicznych. Można przy tym sądzić, że stopień przestrzennego rozkładu zagrożeń jest nierównomierny. Ze szczególną ostrością dotyczy on gleb najsłabszych - wykształconych na podłożu piasku. Ich eksploatacja rolna wywoływała i wywołuje szereg niekorzystnych zmian powierzchniowych - związanych z erozja rolną, denudacją oraz procesami eolicznymi. Choć w oczywisty sposób naruszają one strukturę stanowisk, to stopień ingerencji jest tu dość umiarkowany w porównaniu z orką leśną, budową kopców warzywnych czy eksploatacją kopalin. Szczególnie niepokojących wniosków dostarcza przykład Opok, gdzie w ciąuu ostatnich trzydziestu - czterdziestu lat zniszczono znaczną część stanowisk neolitycznych. Jeśli proces ten nie zostanie powstrzymany, to w dającej się przewidzieć perspektywie bezpowrotnie utracimy resztę z nich. Nie można wykluczyć, że należymy do ostatnich pokoleń mających okazję obserwować i badać obozowiska i osady neolityczne w tej strefie Kujaw. Za bezwzględnie konieczne uznać więc należy wdrożenie mechanizmów respektujących konstytucyjną zasadę zrównoważonego rozwoju, tak abyśmy podołali roli depozytariuszy dziedzictwa kulturowego tej części Kujaw. Towarzyszyć temu powinna realizacja dwuetapowego programu zabezpieczenia substancji zabytkowej. Pierwszy z nich miałby charakter weryfikacyjny - nastawiony na szczegółową lustrację stanowisk już znanych oraz identyfikację nowych źródeł. Współczesne możliwości techniczne w pełni umożliwiają dokładną rejestrację struktury napowierzchniowej dystrybucji zabytków ruchomych (np. w systemie GPS). Uzyskane w ten sposób dane posłużyć powinny szczegółowemu zdiagnozowaniu stanu zachowania poszcze- 
gólnych stanowisk oraz ich grup. W kolejnym etapie źródła szczególnie narażone na zniszczenie oraz posiadające znaczne wartości poznawcze należałoby poddać badaniom wykopaliskowym. Obu etapom powinny towarzyszyć działania edukacyjne, tak aby świadomość odpowiedzialności za przetrwanie świadectw przeszłości była obecna wśród mieszkańców regionu.

prof. dr hab. Seweryn Rzepecki

Uniwersytet Łódzki

Wydział Filozoficzno-Historyczny

Instytut Archeologii

ul. Uniwersytecka 3

90-137 Łódź

\section{Bibliografia}

Źródła

Program Ochrony Środowiska dla gminy Aleksandrów Kujawski na lata 2006-2013, Aleksandrów Kujawski (praca w maszynopisie).

Studium uwarunkowań $i$ kierunków zagospodarowania przestrzennego gminy Aleksandrów Kujawski, 2013, Warszawa (praca w maszynopisie).

Opracowania

Abramów J. (2014), Odciski roślinne na ceramice naczyniowej. Analiza archeobotaniczna, [w:] S. Rzepecki, Wilkostowo 23/24. Neolityczny kompleks osadniczy, Instytut Archeologii UŁ, Łódź, s. 471-508.

Andrałojć A. A., Woźniak M. (1988), Osadnictwo neolityczne $i$ wczesnobrazowe w Opokach woj. wloctawskie, stanowisko 7, Wydawnictwo UAM, Inowrocław.

Chachlikowski P. (1994), Osiedla kultury pucharów lejkowatych w Podgaju woj. włocławskie, stanowisko 6A, UAM, Poznań.

Chachlikowski P. (1997), Kamieniarstwo późnoneolitycznych społeczeństw Kujaw, UAM, Poznań.

Chachlikowski P., Czebreszuk J. (1990), Badania osadnictwa kultury amfor kulistych w rejonie zlewni rzeki Tażyny - Kanału Parchańskiego, [w:] Kultura amfor kulistych w rejonie Kujaw, red. A. Cofta-Broniewska, Wydawnictwo Naukowe UAM, Poznań, s. 355-396.

Czebreszuk J. (1996), Społeczności Kujaw w poczatkach epoki brazu, PSO, Poznań. 
Czebreszuk J., Szmyt M. (2010), Społeczności Niżu Polskiego w III tys. przed Chr.: propozycja interpretacji kulturowo-społecznych, [w:] Mente et rutro. Studia archaeologica Johanni Machnik viro doctissimo octogesimo vitae anno ab amicis, collegis et discipulis oblate, eds. S. Czopek, S. Kadrow, Instytut Archeologii URz, Ressoviae-Mitel, s. 153-165.

Czerniak L. (1988), Czynniki zewnętrzne w rozwoju kulturowym społeczeństw Kujaw $w$ okresie wczesnego i środkowego neolitu, [w:] Kontakty pradziejowych społeczeństw Kujaw z innymi ludami Europy, red. A. Cofta-Broniewska, UM, Inowrocław, s. 55-79.

Czerniak L. (1994), Wczesny i środkowy okres neolitu na Kujawach 5400-3650 p.n.e., IAiE PAN, Poznań.

Czerniak L., Kośko A. (1993), Z badań nad genezq i systematykq kultury pucharów lejkowatych na Kujawach, Uniwersytet im. Adama Mickiewicza w Poznaniu, Poznań.

Danilewicz-Zielińska M. (2000), Biurko Konopnickiej, Open, Warszawa.

Długosz-Kurczabowa K. (2003), Nowy słownik etymologiczny języka polskiego, PWN, Warszawa.

Domańska L. (1988), Rozwój kulturowy społeczeństw Kujaww okresie późnego mezolitu, [w:] Kontakty pradziejowych społeczeństw Kujaw z innymi ludami Europy, red. A. Cofta-Broniewska, UM, Inowrocław, s. 29-43.

Domańska L. (1995), Geneza krzemieniarstwa kultury pucharów lejkowatych na Kujawach, Uniwersytet Łódzki, Łódź.

Domańska L. (2013), Krzemieniarstwo horyzontu klasycznowióreckiego kultury pucharów lejkowatych na Kujawach, Instytut Archeologii UŁ, Łódź.

Domańska L., Forysiak J., Rzepecki J., Twardy J. (2013), The TRB culture settlement in the middle Tażyna Valley: a case study, [in:] Environment and subsistence - forty years after Janusz Kruk's ,Settlement studies...”, red. S. Kadrow, P. Włodarczak, Studien zur Archaologie in Ostmitteleuropa/Studia nad Pradziejami Europy Środkowej, t. 11, Dr. Rudolf Habelt GmbH, Rzeszów-Bonn, s. 105-116.

Domańska L., Rzepecki S. (2001), Osiedla kultury pucharów lejkowatych ze stanowiska Przybranówek 43, gm. Aleksandrów Kujawski w świetle badań przeprowadzonych $w$ latach 1994-1997, „Łódzkie Sprawozdania Archeologiczne", t. VII, s. 13-62.

Domańska L., Rzepecki S. (2009), Chlewiska 132 Site: The Linear Band Pottery Culture Settlement from the Sandy Areas of the Kuyavia Region, [w:] Understanding the Past. Papers Offered to Stefan K. Kozłowski, eds. J. M. Burdukiewicz, K. Cyrek, P. Dyczek, K. Szymczak, Center for Research on the Antiquity of Southeastern Europe, University of Warsaw, Warsaw, s. 107-113. 
Domańska L., Rzepecki S. (2010), Obozowisko ludności kultury ceramiki wstęgowej rytej na stanowisku 2 w Wiktorynie, woj. kujawsko-pomorskie, „Fontes Archaeologici Posnanienses", t. 46, s. 107-126.

Duma J. (1999), Gewässernamen im linken Zuflugßgebiet der Weichsel zwischen Pilica und Brda (Nazwy wodne w zlewsiku lewych dopływów Wisty od Pilicy po ujście Brdy), Franz Steiner Verlag, Stuttgart.

Grygiel R. (2004), Neolit i poczatki brazu w rejonie Brześcia Kujawskiego i Osłonek, Tom I, Wczesny neolit, kultura ceramiki wstegowej rytej, Fundacja Badań Archeologicznych Imienia Konrada Jażdżewskiego, Łódź.

Jaskanis D. (red.) (1992), Katalog archeologicznych zbiorów pozamuzealnych, z. 5, Kolekcja Instytutu Prahistorii Uniwersytetu Adama Mickiewicza w Poznaniu, Cz. 2, ODZ, Warszawa.

Jaskanis D. (1993), Katalog archeologicznych zbiorów pozamuzealnych, z. 5. Kolekcja Instytutu Prahistorii Uniwersytetu Adama Mickiewicza w Poznaniu, Cz. 4, ODZ, Warszawa.

Jaworski A. (2011), Hodowla lasu. Tom I. Sposoby zagospodarowania, odnawiania lasu, przebudowa i przemiana drzewostanów, PWRiL, Warszawa.

Jóźwiak B. (2003), Społeczności subneolitu wschodnioeuropejskiego na Niżu Polskim w międzyrzeczu Odry $i$ Wisty, Uniwersytet im. Adama Mickiewicza, Poznań.

Kośko A. (1981), Udział południowo-wschodnioeuropejskich wzorców kulturowych w rozwoju nizowych spoleczeństw kultury pucharów lejkowatych. Grupa matewska, Wydawnictwo Naukowe UAM, Poznań.

Matuszkiewicz J. M. (2008), Geobotanical regionalization of Poland (Regionalizacja geobotaniczna Polski), IGiPZ PAN, Warszawa, http://www.igipz.pan.pl/ Regiony-geobotaniczne-zgik.html.

Matuszkiewicz J. M. (2010), Geobotaniczna analiza specyfiki regionu kujawsko-pomorskiego, [w:] Ciepłolubne murawy w Polsce. Stan zachowania i perspektywy ochrony, red. H. Ratańska, B. Waldon, Wydawnictwo UKW, Bydgoszcz, s. 11-43.

Okupny D., Fortuniak A., Tomkowiak J. (2014), Zapis procesów prehistorycznej antropopresji $w$ dorzeczu środkowej Tażyny $w$ świetle badań osadów biogenicznych z Wilkostowa, [w:] S. Rzepecki, Wilkostowo 23/24. Neolityczny kompleks osadniczy, Instytut Archeologii UŁ, Łódź, s. 531-540.

Pospieszny Ł. (2009), Zwyczaje pogrzebowe społeczności kultury ceramiki sznurowej w Wielkopolsce i na Kujawach, Wydawnictwo Poznańskie, Poznań.

Przybył A. (2009), Społeczności późnoneolitycznej kultury pucharów lejkowatych na Kujawach. Problem wpływów z kręgu kultury badeńskiej, Wydawnictwo Poznańskie, Poznań. 
Pyzel J. (2010), Historia osadnictwa społeczności kultury ceramiki wstęowej rytej na Kujawach, Instytut Archeologii UG, Wydawnictwo Biblioteka Telgte, Gdańsk.

Rzepecki S. (2004), Społeczności środkowo neolitycznej kultury pucharów lejkowatych na Kujawach, Wydawnictwo Poznańskie, Poznań.

Rzepecki S. (2011), U źródet megalityzmu w kulturze pucharów lejkowatych, Instytut Archeologii UŁ, Łódź.

Rzepecki S. (2013), Beside the mainstream. Some reflections on the LBK in Kujavia, „Sprawozdania Archeologiczne”, t. 65, s. 79-130.

Rzepecki S. (2014), Wilkostowo. Neolityczny kompleks osadniczy, Tom I-II, Instytut Archeologii UŁ, Łódź.

Szmyt M. (1996), Społeczności kultury amfor kulistych na Kujawach, UAM, Poznań.

Szmyt M. (2013), Late Neolithic Landscapes on the Polish Lowland: people, culture and economy in Kujawy - 4th and 3rd millennia BC, Wydawnictwo Naukowe UAM, Dr. Rudolf Habelt GmbH, Poznań-Bonn.

Tarka R. (1992), Tektonika wybranych złóż soli w Polsce na podstawie badań mezostrukturalnych, Prace Państwowego Instytutu Geologicznego 147, Warszawa.

Waszczuk K. (2014), Wyniki analiz archeozoologicznych, [w]: S. Rzepecki, Wilkostowo 23/24. Neolityczny kompleks osadniczy, Instytut Archeologii UŁ, Łódź, S. $429-461$.

Wilkoń-Michalska J. (1963), Halofity Kujaw, Studia Societatis Scientiarum Torunensis, Sectio D (Botanica), vol. VII, nr 1, Toruń.

Wilkoń-Michalska J. (1971), Szata roślinna Kujaw. Przewodnik florystyczny, PWN, Torun.

Wiślański T. (1969), Podstawy gospodarcze plemion neolitycznych w Polsce pótnocno-zachodniej, Ossolineum, Wrocław.

\section{SUMmary}

\section{SOME REFLECTIONS ON THE PROSPECTS OF THE NEOLITHIC SITES PRESERVATION IN THE TĄŻYNA RIVER BASIN}

The Tążyna river is one of not large Kuyavian tributaries of the Vistula river. A unique feature of this river catchment area is a very high degree of biodiversity. It comprises, among others, the co-occurrence of zones of various lithology and genesis (morainic plains, valleys with outwash plain formations, outwash plains with holes) and relatively shallow occurrence of salt deposits supplying the groundwater with brine. They are 
accompanied by the occurrence of halophytes. The discussed region also abounds in numerous archaeological sources dated to the Neolithic. They document complicated processes of the Tazżyna basin domestication. They were initiated by the appearance of agricultural societies of the Linear Pottery culture exploiting the environment of soils with the highest agricultural values. These groups also made an attempt of "tactical" use of podzols environments, however, due to its failure within the following centuries, they concentrated on earlier exploited areas. A real breakthrough was brought by the occurrence of the Funnel Beaker culture societies. They were mainly interested in less abundant, hitherto not used in terms of economy, environments. Probably at that time brine springs were also exploited. An excellent example of a settlement from this period is Wilkostowo 23/24 - one of the best recognized complexes of ,funnel beakers" in Europe. In the following centuries the Tążyna basin was the scene of activeness of societies realising more mobile (,globular amphoras” and „corded ware”) economic strategies.

The state of preservation and prospects of the Neolithic sites survival adversely correspond to the outstanding cognitive significance of the region under consideration. During the recent thirty - forty years a sharp increase of threats to part of them-especially to these located on the weakest soils (developed on sandy substratum) took place. Their areas are nowadays afforested, objects connected with vegetables storage are located on them, and they become purposes of minerals (sand, gravel) exploitation. In such a situation it is necessary to implement a local programme of protection of sites dated to the Neolithic. The author postulates that it should include verifying surface surveys, excavations and educational actions. 